Original Research Paper

\title{
Introduksi Produksi Benih Kentang Dengan Teknik Penyetekan pada Kelompok Penangkar di Kawasan Sembalun Lombok Timur
}

\author{
M. Sarjan ${ }^{1}$, Aluh Nikmatullah ${ }^{2}$, Hery Haryanto², Irwan Muthahanas $^{2}$

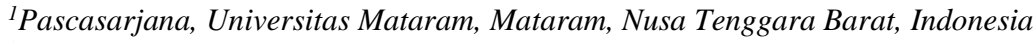 \\ ${ }^{2}$ Program Studi Agroekoteknologi, Fakultas Pertanian, Universitas Mataram, Mataram, Indonesia
}

https://doi.org/10.29303/jpmpi.v3i2.607

Sitasi: Sarjan, M., Nikmatullah, A., Heryanto, H., \& Muthahanas, I. (2021). Introduksi Produksi Benih Kentang Dengan Teknik Penyetekan pada Kelompok Penangkar di Kawasan Sembalun Lombok Timur. Jurnal Pengabdian Magister Pendidikan IPA, 4(1)

\author{
Article history \\ Received: 05 Desember 2020 \\ Revised: 30 Desember 2020 \\ Accepted: 29 Januari 2021 \\ *Corresponding Author: \\ M. Sarjan, Pascasarjana, \\ Universitas Mataram, Mataram, \\ Nusa Tenggara Barat, \\ Indonesia \\ Email: msarjan@unram.ac.id
}

\begin{abstract}
Kelembagaan yang ada di tingkat petani (kelompok tani) memiliki potensi yang cukup baik untuk dilakukan pembinaan penangkaran perbenihan. Jika penangkaran benih bisa berkembang di tingkat kelompok tani maka kebutuhan akan benih dapat dipenuhi oleh kelompok tani tersebut, sehingga biaya pengadaan benih relatif lebih murah dan akan menambah pendapatan bagi kelompok tani. Dengan demikian keberadaan benih tidak terlalu jauh dari pengguna, sehingga para petani mudah mendapatkan benih yang bermutu, dan juga memberikan nilai tambah bagi kelompok tani. Kecamatan Sembalun merupakan salah satu kecamatan di Kabupaten Lombok Timur yang memiliki potensi pengembangan budidaya hortikultura dataran tinggi termask kentang dengan daya dukung sumberdaya alalam yang melimpah dan tingkat kesesuaian lahan yang cocok untuk tumbuh dan berkembangnya tanaman kentang dengan optimal. Hasil kegiatan ini menunjukan Kelompok Penangkar Benih Kentang di Sembalun sangat tertarik untuk menerapkan teknologi produksi benih melalui penyetekan pucuk berulang, namun belum mempunyai sarana yang cukup untuk menerapkan teknologi secara mandiri. Keterampilan penyetekan pucuk berulang dari sebagian anggota kelompok penangkar sudah memadai Hasil umbi dari sumber stek masih lebih rendah secara individu tanaman dibanding dengan yang berasal dari umbi. Tetapi secara akumulatif dalam satu musim tanam lebih banyak, sehingga akan membantu penyediaan benih kentang dikawasan Sembalun. Diperlukan perhatian khusus dari instansi terkait seperti Dinas Pertanian melalui UPT BBI untuk membantu sarana screen house. Perlu pendampingan secara berkelanjutan baik dari Perguruan Tinggi maupun dari Instansi Pemerintah terkait agar diperoleh kelompok penangkar benih kentang yang maju dengan inovasi teknologi pertanian yang ada.
\end{abstract}

Keywords: Kentang; Penyetekan; Penangkar benih Sembalun.

\section{Pendahuluan}

Upaya peningkatan produksi kentang di Indonesia dihadapkan pada kendala yang berhubungan dengan manajemen produksi dan ketersediaan benih bermutu yang sangat terbatas (Ranu, 2009). Sampai dengan tahun 2008, produksi benih kentang nasional baru bisa memenuhi hanya $8,3 \%$, sehingga sisanya dipenuhi dari oleh benih impor $(1 \%)$ dan lebih dari $90 \%$ dipenuhi dengan benih yang diproduksi oleh petani tanpa asal usul yang jelas (Anonim, 2006). Benih kentang yang diimpor adalah benih kentang Atlantis, sedangkan benih kentang produksi nasional umumnya adalah benih varietas Atlantis dan Granola serta beberapa 
varietas lokal lainnya Penangkar benih kentang terbesar di Indonesia adalah daerah Jawa Barat, Sumatra Utara dan Jambi, Jawa Tengah yang masih jauh dibawah kebutuhan benih, dan menunjukkan bahwa produksinya bahkan belum mencukupi kebutuhan benih lokal di provinsi produsennya.

Tingginya permintaan dan rendahnya produksi benih ini menunjukkan besarnya potensi secara nasional akan kebutuhan benih bersertifikat tersebut. Meskipun terdapat kompetitor, akan tetapi peluang pasar masih jauh lebih besar. Kompetitor lain adalah produsen benih impor, namun ketersediaan benih impor juga terkendala berbagai persoalan termasuk kontinuitas ketersediaan, terbawanya penyakit, masalah karantaina dan lainnya.

Langkah strategis untuk mengatasi hal tersebut adalah pengembangan perbenihan kentang nasional bersertifikat melalui pengembangan sentra yang telah terbentuk dan kawasan baru potensial, seperti Kawasan Sembalun NTB yang memiliki kesesuaian agroklimat dan keunggulan kompetitif wilayah karena terbebas dari nematoda sista kuning (NSK), penyakit yang sangat ditakuti oleh petani kentang dunia. Meskipun telah dilakukan pembinaan calon penangkar oleh instansi berwenang (Anonim, 2010), upaya produksi benih kentang bersertifikat di NTB belum berhasil. Penyebabnya antara lain adalah keterbatasan penguasan teknologi dan belum terbentuknya rantai sistem produksi di NTB yang meliputi produksi plantlet bebas virus melalui kultur jaringan, produksi umbi Go (Benih penjenis), G1 dan G2 (Benih Dasar) serta benih G3 (Benih Pokok) dan G4 (Benih sebar) serta dibarengi dengan pengujian dan sertifikasi benih (Abdurrachman, 2000; Suwarno, 2008). Disisi lain, Universitas Mataram memiliki teknologi tersebut dan telah berhasil memprodukdi bibit kentang benas virus melalui kultur jaringan. Universitas Mataram telah bersinergi dengan BBI TPH untuk memproduksi benih Go bebas virus, dan rantai produksi G1 sampai G3 telah terbentuk melalui kegiatan RUSNAS 2013-2015 dan dihasilkan benih kentang bersertifikat dari Nusa Tenggara Barat.

Kelembagaan yang ada di tingkat petani (kelompok tani) memiliki potensi yang cukup baik untuk dilakukan pembinaan penangkaran perbenihan. Jika penangkaran benih bisa berkembang di tingkat kelompok tani maka kebutuhan akan benih dapat dipenuhi oleh kelompok tani tersebut, sehingga biaya pengadaan benih relatif lebih murah dan akan menambah pendapatan bagi kelompok tani. Dengan demikian keberadaan benih tidak terlalu jauh dari pengguna, sehingga para petani mudah mendapatkan benih yang bermutu, dan juga memberikan nilai tambah bagi kelompok tani. Kecamatan Sembalun merupakan salah satu kecamatan di Kabupaten Lombok Ti,ur yang memiliki potensi pengembangan budidaya hortikultura dataran tinggi termask kentang dengan daya dukung sumberdaya alalam yang melimpah dan tingkat kesesuaian lahan yang cocok untuk tumbuh dan berkembangnya tanaman kentang dengan optimal.

Kegiatan ini ingin membantu mitra "Kelompok Tani Bumbung Hijau dan Al Ichlas" untuk memproduksi benih kentang yang bermutu bersertifikat dan menjadikan kelompok tani ini sebagai penangkar benih (Seed Grower). Keberadaan penangkar benih ini diharapkan dapat mensuplai benih pada budidaya kentang khususnya ditingkat lokal kawasan Sembalun . Adanya penangkar Benih kentang ini sekaligus dapat meningkatkan income generating dari "Kelompok Tani Bumbung Hijau dan Al Ichlas " dan permasahan penyediaan benih bermutu untuk petani di Kawasan Sembalun khususnya dan di Kabupaten Lombok Timur pada umumnya dapat diatasi. Selanjutnya penggunaan benih bermutu bersertifikasi diharapkan juga dapat meningkatkan produksi kentang dan akhirnya dapat meningkatkan pendapatan petani.

Beberapa permasalahan perbenihan kentang di lokasi mitra antara lain :

1. Kurangnnya kelompok penangkar (baru terbentuk melalui kegiatan RUSNAS), sehingga penyediaan benih kentang bersertifikasi nasional masih belum bisa terpenuhi di kawasan Sembalun.

2. Kurang tersosialisasinya ketersediaan benih berserttifikasi nasional di tingkat lapangan yang mengakibatkan petani tidak mengetahui akan benih yang berkualitas dan bersertifikasi nasional

3. Kurang optimalnya pelaku perbenihan di tingkat daerah, sebagai contoh benih yang diproduksi di tempat perbenihan formal hanya untuk kepentingan terbatas saja, sehingga benih di tingkat petani sangat jauh dari pemenuhan kebutuhan dan belum berkelanjutan. 
4. Penyetekan merupakan teknik yang cukup mudah dan cepat untuk menghasilkan benih kentang dalam jumlah yang banyak telah diperkenalkan oleh Tim UNRAM, namun teknologi ini belum dikenal oleh banyak petani.

Dalam pembinaan kelompok tani perlu dilihat kesiapan atau minat kelompok tani apakah sudah memiliki kelembagaan yang baik, ini akan menentukan tingkat keberhasilan dalam pembinaan penangkaran perbenihan. Untuk memperkecil kendala dalam pembinaan penangkaran benih kentang, pemilihan kelompok tani merupakan kunci utama dalam mengatasi kendala yang akan muncul. Kelompok tani harus memiliki jiwa usaha sehingga kelompok tani mampu menangkap peluang dalam usaha perbenihan yang di kelolanya.

Petani sampai saat ini masih mempunyai pengetahuan dan keterampilan yang terbatas tentang benih dan penangkaran, sehingga sangat btergantung dengan penangkar dari luar. Di samping itu kebiasaan petani menggunakan benih yang tidak bermutu seperti ini juga menyebabkan rendahnya produksi kentang di tingkat petani.

Berdasarkan hasil Kegiatan Peeitian Unggulan Strategis Nasional (2013-2014) lalu telah menghasilkan kelompok penangkar benih kentang, terungkap bahwa petani sangat menginginkan untuk menjadi penangkar benih kentang yang sampai saat ini belum banyak di lokasi kegiatan di Kecamatan Sembalun Kabupaten Lombok Timur.

\section{Metode}

Pemecahan masalah yang akan dilakukan pada kegiatan ini adalah produksi benih kentang bermutu G1 dari sumber dengan teknik penyetekan dan menjadikan kelompok tani "Kelompok Tani Bumbung Hijau dan Al Ichlas" sebagai penangkar benih (seed grower) kentang untuk mensuplai benih bermutu bagi kelompok tani sendiri dan petani di luar kelompok tani.

\section{Metode pendekatan}

Kegiatan IbM ini menggunakan Metode Andragogi, yaitu dengan menekankan dan menerapkan pendekatan Program Tindak Partisipatif (Partisipatory Action Program) dari peserta melalui pelatihan, diskusi, kerja kelompok dan demonstrasi lapangan (Demplot) pada seluruh kegiatan.

\section{Penentuan lokasi kegiatan dan target peserta}

Kegiatan ini dilaksanakan di Desa Timbe Gading Kecamatan Sembalun Kabupaten Lombok Timur yang merupakan sentra tanaman kentang dataran tinggi. Peserta terdiri atas 30 orang petani yang berasal dari dua Kelompok Tani, yaitu Kelompok Tani Bumbung Hijau dan Kelompok Tani Al Ichlas di Desa Timbe Gading Kecamatan Sembalun Lombok Timur, yang bekerja aktif di lahannya tanpa melihat status kepemilikan lahan.

\section{Pelaksanaan}

Pelaksanaan kegiatan ini dilaksanakan selama dua tahapan, yaitu:

\section{a. Tahapan persiapan}

Identifikasi masalah, kemudian survey pendasaran menggunakan metode deskriptif eksploratif dengan tujuan untuk memperoleh data lengkap mengenai aspek sosial, ekonomi dan budaya petani.

\section{b. Tahapan pelaksanaan}

Pelaksanaan diawali dengan pelatihan yang meliputi $20 \%$ teori dan $80 \%$ praktek lapang. Kegiatan pelatihan meliputi pre test, penyampaian modul, penjelasan materi (dengan LCD dan alat peraga), diskusi dan tanya jawab, dan post test, kemudian dilanjutkan dengan DEMPLOT.

\section{Demonstrasi plot}

Demonstrasi plot dan praktek produksi benih dilakukan di lahan petani. Petani secara partisipatif ikut terlibat secara bersama-sama dari perencanaan, pelaksanaan dan evaluasi hasil panen.

Areal demplot dilakukan pada tanah petani seluas 10 are. Kegiatan penyetekan dilakukan di screen house milik Pemda Provinsi NTB, sedangkan penanaman benih hasil stek dilakukan di lahan petani. Setelah melakukan pelatihan teknis secara teoritis di kelas, kelompok tani mendapatkan praktek tentang penyetekan benih kentang dan budidaya produksi benih asal stek. Tim memberikan pelayanan teknis kepada petani dengan mengundang partisipatif petani mulai dari penyusunan/perencanaan program, pelaksanaan kegiatan (menanam, memelihara, panen, dan perlakuan benih di gudang penyimpanan), membandingkan, dan memutuskan apakah program yang dilaksanakan memberi keuntungan atau tidak. 


\section{Rancangan evaluasi}

Penilaian terhadap keberhasilan kegiatan berpedoman pada:

- Kesesuaian antara topik action research yang dilaksanakan.

- Kehadiran dan partisipasi para peserta disetiap kegiatan sejak persiapan sampai berakhirnya kegiatan mencerminkan keinginan dari peserta untuk mengetahui dan mengadopsi teknologi yang diperkenalkan oleh Tim Pelaksana.

- Sikap dan tanggapan dari para peserta terhadap kegiatan yang dilaksanakan.

- Hasil pre-test dan post-test pada peserta.

\section{Hasil dan Pembahasan}

\section{Pengusulan dan Sosialisasi Teknologi}

Beberapa hal penting yang dihasilkan pada kegiatan sosialisasi teknologi penggunaan stek untuk produksi benih kenang tersebut adalah sebagai berikut:

a. Keinginan sangat kuat dari penangkar benih di Sembalun untuk dapat melakukan penangkaran dan memproduksi benih secara mandiri.

b. Penangkar memiliki harapan yang besar agar dari kegiatan Rusnas dapat terbentuk rantai pasokan produksi benih kentang di Sembalun.

c. Penangkar mengharapkan bimbingan atau program magang dalam penangkaran benih kentang.

d. Penangkar mengharapkan adanya dukungan prasarana untuk penangkaran benih kentang.

e. Mengharapkan agar institusi produsen benih Go berlanjut setelah Rusnas berakhir.

f. Permasalahan dalam hal permodalan.

g. Mengharapkan dukungan kebijakan dalam penggunaan benih yang diproduksi oleh penangkar lokal.

Beberapa hal yang ditanggapi oleh Dinas Pertanian dan BBI TPH adalah dukungan terhadap sarana prasarana akan menyediakan 5 buah screen house G1 bagi penangkar benih G1, sedangkan pembimbingan akan dilakukan oleh Fakultas Pertanian Universitas Mataram khusunya tim peneliti Rusnas. Visualisasi kegiatan FGD ditampilkan pada Gambar berikut.

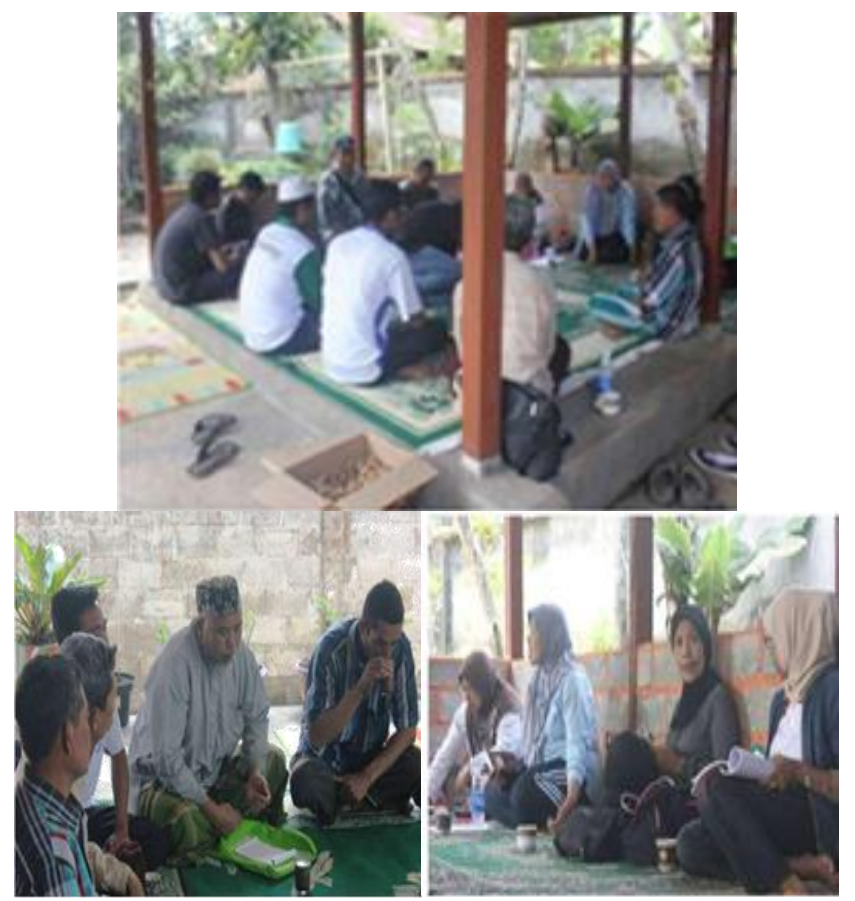

Gambar 1. Visualisasi diskusi dengan penangkar dan pemuka masyarakat Sembalun

\section{Kegiatan Pengenalan Teknologi Penyetekan kentang}

a. Optimasi Aklimatisasi Plantlet

Berdasarkan hasil survey dan wawancara awal dengan petani dan penangkar di Kecamatan Sembalun diketahui bahwa ada 2 kelompok pembudidaya tanaman kentang, yaitu kelompok petani yang memiliki kontrak produksi dengan PT Indofood, yaitu yang tergabung dengan Gapoktan Horsela, untuk memproduksi kentang varietas Atlantis dan kelompok petani yang tidak terikat kontrak dengan Indofood yang memproduksi varietas kentang sayur (Granola) untuk kebutuhan pasar lokal dan Bali. Selain produksi untuk

Indoffod terdapat juga sebagian kecil petani yang menghasilkan kentang jenis Atlantis untuk kebutuhan industri kecil. Dalam hal kebutuhan benih, benih untuk kelompok tani Horsela disediakan oleh PT Indofood, sedangkan benih untuk produsen jenis Granola disediakan dengan membeli benih dari daerah lain atau dari penangkar yang memperoleh benih $\mathrm{G}_{3}$ dari Pengalengan. 


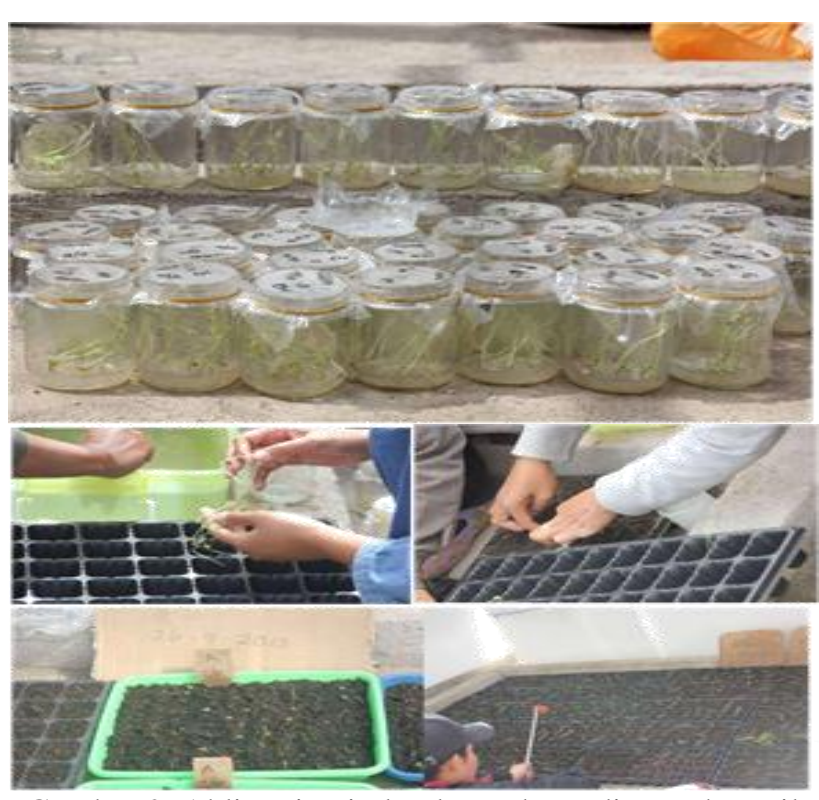

Gambar 2. Aklimatisasi plantlet pada media tanah steril dengan seed tray dan pada media campuran arang sekam dan cocopeat yang ditanam secara berkelompok.

Kegiatan penanaman diawali dengan aklimatisasi plantlet varietas Granola dan Atlantis yang diperoleh dari Unit IbIKK Universitas Mataram. Plantlet dibawa ke Screen House dan kemudian dikeluarkan dari botol, dan agar yang menempel dibuang lalu akar direndam dengan larutan fungisida (selama 5 menit) dan sebagian akarnya direndam dengan NAA dan sebagian tidak direndam dengan NAA. Tanaman kemudian ditanam dalam 2 media berbeda: 1) media tanah steril dalam seed tray, atau 2) media campuran cocopeat dan arang sekam (ditanam secara berkelompok sebanyak 70 plantlet per tray (Gambar 2).

Prosentase keberhasilan aklimatisasi pada aklimatisasi awal ini cukup kecil dimana hanya 20 - $25 \%$ plantlet berhasil diaklimatisasi dari 2000 plantlet yang dikeluarkan dari dalam botol, dimana aklimatiasi menggunakan media campuran cocopeat dan arang sekam menghasilkan prosentase plantet hiduo (setelah 1 minggu aklimatisasi) adalah lebih tinggi dari penanaman pada seed tray dengan media tanah steril.Salah satu penyebab tingginya kematian plantlet pada saat aklimatisasi ini adalah suhu yang tinggi di dalam screen house, dimana suhu di dalam screen jauh lebih tinggi dari suhu di luar, untuk mengatasi hal tersebut maka dipasangkan sistem fogging di dalam screen untuk pengkabutan otomatis yang dilakukan pada pukul 11 siang dan 14 siang. Setelah aklimatisasi pertama dilakukan aklimatisasi kedua menggunakan media cocopeat dan arang sekam dengan meletakkan plantlet secara berkelompok.

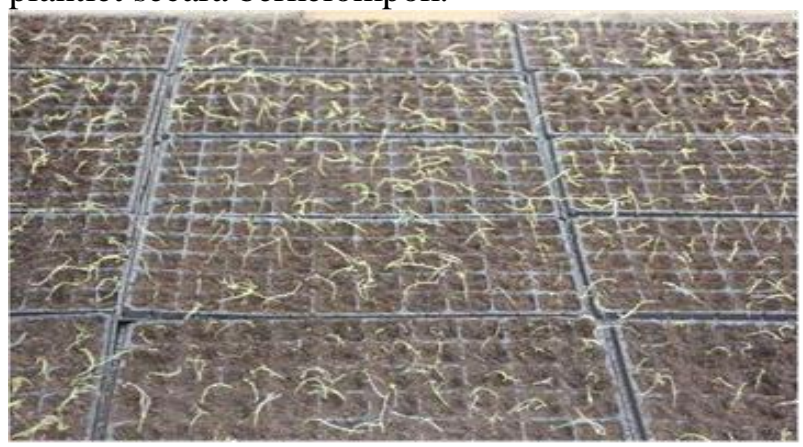

Gambar 3. Perkembangan plantlet 7 hari setelah aklimatisasi pada media campuran tanah steril di seedling tray

\section{b. Optimasi Perbanyakan bibit dengan Stek} Plantlet

Salah satu teknologi yang dikembangkan untuk menghasilkan bahan tanam steril dalam jumlah yang memadai adalah melalui perbanyakan plantlet hasil aklimatisasi melalui stek-mini. Beberapa pustaka menyebutkan bahwa stek mini langsung dibuat dari plantlet dengan melakukan stek single node, dan merangsang pengakaran dengan auksin, akan tetapi teknik tersebut tidak berhasil dalam penelitian ini (persentase tunas tumbuh kurang dari 25\%). Oleh karenaya dilakukan optimasi produksi stek menggunakan plantlet yang telah diaklimatisasi dan stek plantlet langsung tanpa aklimatisasi dan menggunakan stek dengan ukuran 1 buku, 2 buku dan 3 buku. Stek tersebut ditanam di Screen House-2 pada media campura cocopeat dan arang sekam dan diberikan nutrisi hidroponik (campuran nutrisi A dan B).

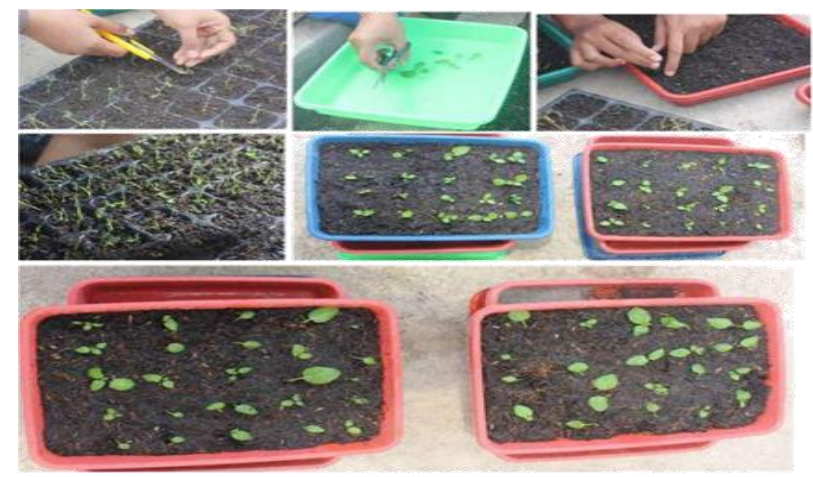

Gambar 4. Stek mini plantlet dan stek yang dihasilkan

Pertumbuhan Stek (3 minggu setelah penyetekan) ditampilkan pada Tabel 1: 
Tabel 1. Pertumbuhan Stek setelah 3 minggu:

\begin{tabular}{lcccc}
\hline Varietas & Tinggi Tanaman $(\mathrm{cm})$ & Jumlah Daun & Jumlah Akar & Panjang Akar $(\mathrm{cm})$ \\
\hline Atlantis & 6,1 & 7 & 3,7 & 14,9 \\
\hline Granola & 9,1 & 7,6 & 6,2 & 6,5 \\
\hline
\end{tabular}

c. Produksi Benih $\mathrm{G}_{0}$ Secara Hidroponik

Sebelum dilakukan penanaman, terlebih dahulu dopersiapkan media hidroponik yaitu campuran cocopeat dan arang sekam (1:5). Untuk setiap bak hidroponik diperlukan 12 karung arang sekam dan 1,5 karung cocopeat. Media disiram dan stek mini yang telah berakar (2 mst) dipindahkan ke media hidroponik dan ditanam dengan jarak tanam $25 \times 25 \mathrm{~cm}$ (Gambar 5).

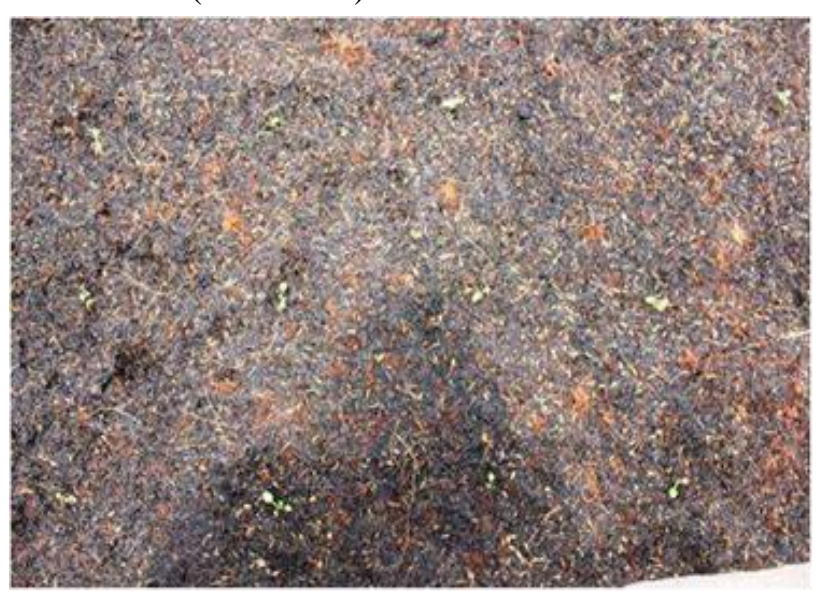

Gambar 5. Penanaman stek mini pada media hidroponik

Setelah penanaman, di bagian atas pertanaman diberikan paranet untuk selama tahap adaptasi (seminggu) dan tanaman dipelihara dengan melakukan penyiraman dengan nutrisi sebanyak 3 kali sehari, fogging screen house 2 kali sehari (siang hari) dan pengendalian vector virus, hama dan penyakit dengan insektisida dan fungisida. Sebagain besar stek yang ditanam tumbuh dengan baik pada media hidroponik, namun terdapat sebagian kecil tanaman yang mati, dan untuk tanaman yang mati dilakukan penyulaman. Setelah seminggu pengadaptasian pada media hidroponik (kultur agregat), paranet dibuka untuk memberikan kondisi pertumbuhan yang optimal pada tanaman. Pertumbuhan tanaman ditampilkan pada Gambar 6.

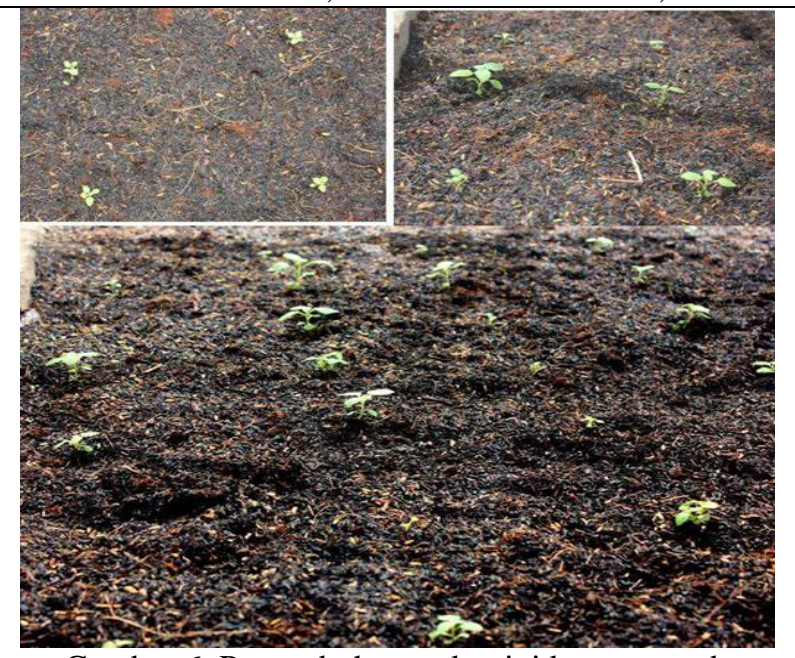

Gambar 6. Pertumbuhan stek mini kentang pada media hidroponik 1 minggu setelah transplanting

(kiri atas) dan 2 minggu setelah transplanting (kanan atas dan bawah)

Setelah bibit berumur 3 minggu setelah tanam, dilakukan perubahan pada pola pemeliharaan, yaitu penyiraman dengan nutrisi dilakukan 3 kali sehari yaitu pada pukul 08.00, pukul 11.00 dan pukul 15.00. Selain pemberian nutrisi, dilakukan juga penyiraman untuk menurunkan suhu di dalam ruang penanaman. Pengendalian hama dan penyakit dilakukan dengan penyemprotan dengan fungisida sistemik setiao dua minggu sekali dan insentisida setiap dua minggu sekali yang ditambahkan dengan perekat. Selain itu, diletakkan juga perekat yang dibuat dari tabung/pipa yang dicat warna biru dan diberi lem, dan disekitarnya diberikan bak berisi insektisda. Fungisida dan pestisida yang digunakan adalah Antracol dan Okrite dengan perekat Besmore. Hama-hama yang ditemukan adalah ulat Spodoptera dan keong. Pemeliharaan lain adalah mengurangi masuknya vactor dengan menutup lubang-lubang yang ada disela screen house dengan lantai screen house. 

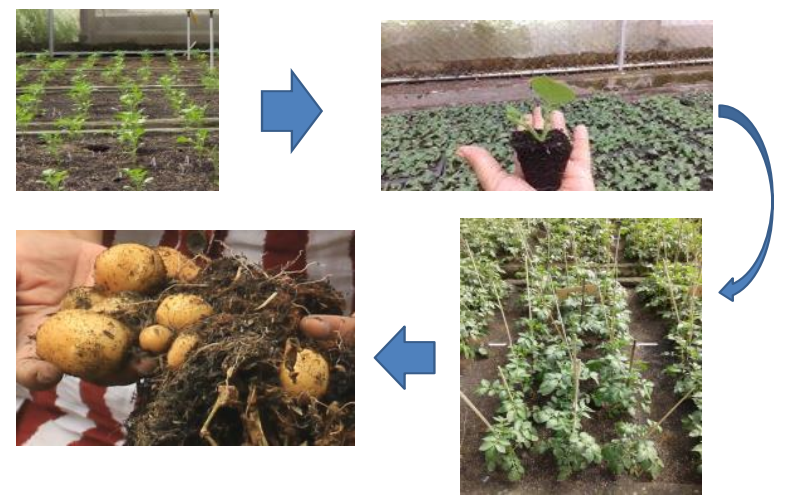

Gambar. 7 Alur Produksi Benih kentang dari stek pucuk berulang

d. Optimalisasi Produksi Benih $\mathrm{G}_{1}$ Secara Hidroponik
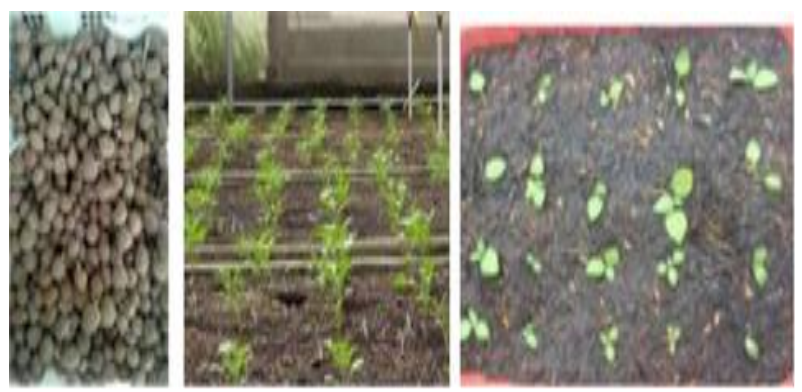

Gambar 8. Sumber benih yang digunakan (kiri), tanaman induk $\mathrm{G}_{0}$ umur 2 minggu sebagai sumber stek (tengah) dan stek pucuk pada tray benih (kanan).

Selama penyetekan dilakukan penyiapan media tanam yaitu campuran arang sekam dan cocopeat (5:1). Media diperlakukan dengan pupuk dasar yaitu pupuk NPK Ponska (2 kg/bak, SP36 sebanyak $2 \mathrm{~kg} / \mathrm{bak}$, Vertigrow sebanyak $20 \mathrm{~kg} / \mathrm{bak}$ (ukuran bak 2,25 m x 10,8 m). Pupuk dicampur merata lalu dibagi menjadi blok-blok perlakuan (27 blok) dengan ukuran $2,25 \mathrm{~m}$ x 0,8 m dan jarak antar plot $50 \mathrm{~cm}$. Stek berumur 2 minggu yang telah berakar selanjutnya dipindahkan pada plot perlakuan dengan jarak tanam bervariasi sesuai perlakuan ( $15 \times 15 \mathrm{~cm}, 15 \times 20 \mathrm{~cm}$ dan $20 \times 20 \mathrm{~cm})$ sehingga diperoleh populasi tanaman yang berbeda per plot (30 sampai 55 tanaman per plot) (Gambar 8).

Hasil panen menunjukkan bahwa setiap stek menghasilkan $3-4$ umbi $\mathrm{G}_{1}$, dimana jarak tanam berpengaruh terhadap produksi benih $G_{1}$ dimana berat per umbi dan berat total umbi per tanaman meningkat dengan meningkatnya jarak tanam, namun total produksi per plot lebih rendah karena populasi tanaman yang lebih sedikit dibandingkan dengan populasi tanaman yang ditanam dengan jarak tanam yang rapat (Gambar 9).
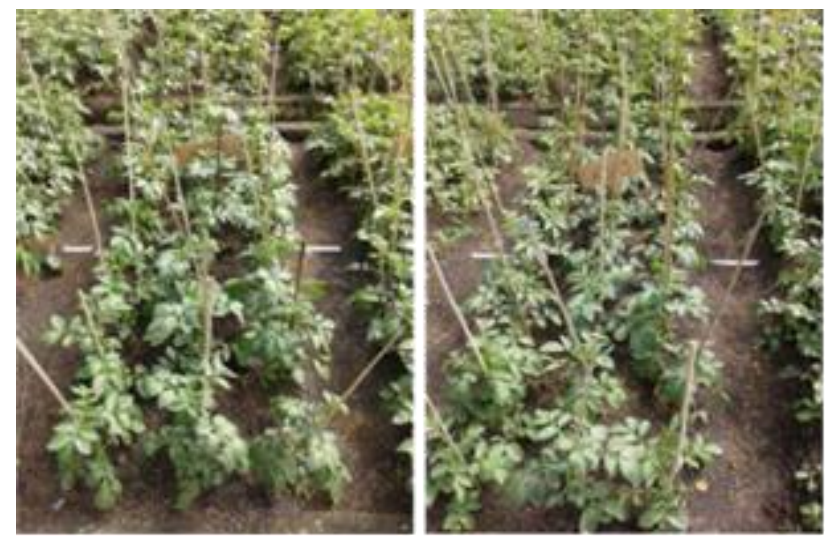

Gambar 9. Visualisasi tanaman G0 hasil stek pucuk pada umur 3 minggu setelah pindah tanam dengan populasi yang berbeda (jarak tanam berbeda)
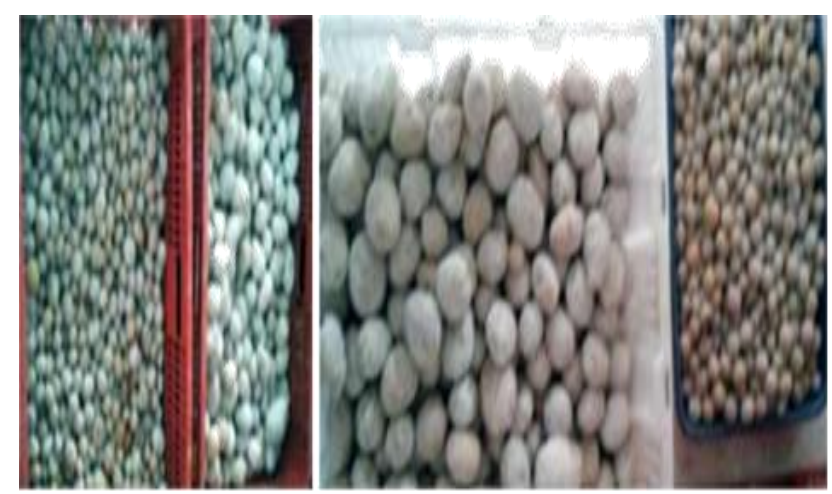

Gambar 10. Keragaan ukuran benih G1 yang dihasilkan dari stek pucuk benih G0 yang ditanam dengan jarak tanam (populasi) berbeda.

\section{Kesimpulan}

a. Kelompok Penangkar Benih Kentang di Sembalun sangat tertarik untuk menerapkan teknologi produksi benih melalui penyetekan pucuk berulang.

b. Kelompok Penangkar belum mempunyai sarana yang cukup untuk menerapkan teknologi secara mandiri.

c. Keterampilan penyetekan pucuk berulang dari sebagian anggota kelompok penangkar sudah memadai.

d. Hasil umbi dari sumber stek masih lebih rendah secara individu tanaman dibanding dengan yang berasal dari umbi. Tetapi 
secara akumulatif dalam satu musim tanam lebih banyak, sehingga akan membantu penyediaan benih kentang dikawasan Sembalun.

\section{Ucapan Terima Kasih}

Ucapan Terima kasih kepada Kepala UPT BBI Provinsi NTB yang telah berkontribusi pada kegiatan ini terutama dalam penyediaan sarana screen house selama demplot dan dalam pendampingan praktik

\section{Daftar Pustaka}

Abdurrachman, 2000. Sertifikasi benih kentang menjamin kebenaran kualitas

Anonim, 2009. Program Unggulan Dinas Pertanian Provinsi Nusa Tenggara Barat, Pemda NTB.

Anonim, 2010. Peningkatan Kapasitas Petani Untuk Menjadi Penangkar Benih Kentang di Kawasan Sembalun Lombok Timur. BPTP Provinsi NTB.

Badan Standar Nasional, 2004. SNI 01-7000-2004 Benih Kentang (Solanum tubersoum L.) Kelas Benih Dasar G2.

Badan Standar Nasional, 2004. SNI 01-7001-2004 Benih Kentang (Solanum tubersoum L.) Kelas Benih Pokok G3.

Badan Standar Nasional, 2004. SNI 01-7002-2004 Benih Kentang (Solanum tubersoum L.) Kelas Benih Sebar G3.

Dimyati A., 2008. Kebijakan Pemerintah Dalam Pengembangan Kentang di Indonesia. Ditjen Hortikultura, Kementerian Pertananian, RI.

Direktorat Perbenihan Hortikultura, Direktorat Jenderal Hortikultura, Kemernterian Pertanian, 2014. Teknis Perbanyakan dan Sertifikasi Benih Kentang. Peraturan Menteri Pertanian RI Nomor 20/kpts/IV/2014.

Irawan B., Winarno M., Agustin N.K., Sinuraya J.F., 2007. Assessment of Horticulture Seed Industry, USAID, Jakarta.
Ranu N.L., 2009. Aturan Perbenihan dan Pengembangan Industri Benih Kentang di Indonesia. Direktorat Jenderal Hortikultura. Kementerian Pertanian Republik Indonesia.

Suwarno W.B., 2008. Sistem Perbenihan Kentang di Indonesia. Ditulis tahun 2000 dan dipubilkasikan kembali tahun 2008 melalui http://www.situshijau.co.id. Instutut Pertanian Bogor.

Wattimena G.A., 2000. Pengembangan Propagul Kentang Bermutu dan Kultivar Kentang Unggul dalam Mendukung Peningkatan Produksi Kentang di Indonesia. Orasi Ilmiah Guru Besar Tetap Ilmu Hortikultura. Fakultas Pertanian, Institut Pertanian Bogor. 86 halaman. 